\title{
SU NĖŠTUMU SUSIJĘS ATIPINIS HEMOLITINIS UREMINIS SINDROMAS: ATVEJO APRAŠYMAS
}

\author{
Diana Maldžiūtė ${ }^{1}$, Ernesta Mačioniene் ${ }^{2}$, Marius Miglinas ${ }^{3}$, Laurynas Rimševičius ${ }^{4}$ \\ ${ }^{1}$ Vilniaus universiteto Medicinos fakultetas, ${ }^{2,3,4}$ Vilniaus universiteto Medicinos fakultetas, \\ Klinikinès medicinos institutas, Gastroenterologijos, nefrourologijos ir chirurgijos klinika
}

Raktažodžiai: nèštumas, preeklampsija, trombinès mikroangiopatijos, ūminis inkstų pažeidimas, aHUS.

\begin{abstract}
Santrauka
Ivadas. Hemolizinis ureminis sindromas (HUS) priklauso ligų, kurios vadinamos trombinèmis mikroangiopatijomis (TMA), grupei. TMA sukelia mažuju kraujagyslių sienelių sustorejjimą ir spindžio obstrukciją, kuri pasireiškia mechanine neimunine hemolizine anemija, trombocitopenija ir, HUS atveju, išemijos sukeltu ūminiu inkstų pažeidimu. Su nèštumu susijęs atipinis HUS (PHUS) pasitaiko 1/25000 gimdyvių per metus ir gali joms sukelti dauginị organų pažeidimą. $60-70$ proc. moteru po pirminès HUS atakos išsivysto paskutinès stadijos inkstų liga.

Klinikinis atvejis. Pristatome 43 metų moterį, kuriai trečią něštumo trimestrą (34-ą nëštumo savaitę) buvo diagnozuota preeklampsija. Trečią hospitalizacijos dieną pacientei atlikta cezario pjūvio operacija. Antrą parą po jos moteriai pasireiškẻ hemolizinè anemija (hemoglobinas $66 \mathrm{~g} / \mathrm{l}$, laktato dehidrogenazè $503 \mathrm{U} / \mathrm{l}$, haptoglobinas $<0.77 \mathrm{~g} / \mathrm{l})$, trombocitopenija $\left(75^{*} 10^{9} / 1\right)$ ir dializès reikalaujantis ūminis inkstų pažeidimas. Kepenų fermentų ir proteazès, surišančios Von Vilebrando faktorių (ADAMTS13) aktyvumas buvo normos ribose, todèl pacientei diagnozuotas PHUS. Moteris buvo gydyta plazmaferezėmis (14 procedūrų). Inkstų funkcija atsistate po 6 hemodializès procedūrų. Beta adrenoblokatoriai ir angiotenzino II receptoriu antagonistai buvo skirti hipertenzijai gydyti.

Išvados. PHUS turètų būti ịtartas, jei pacientei trijų mėnesių laikotarpiu po gimdymo atsirado anemija, trombocitopenija ir ūminis inkstų pažeidimas. PHUS diferencijuojamas su trombine trombocitopenine purpura (TTP), HELLP (hemolizè, padideję kepenų fermentai, mažas trombocitų skaičius) sindromo ir ūminès néščiųų steatozès. Komplementą reguliuojančių
\end{abstract}

baltymų genų mutacijos randamos moterims su preeklampsija, o atipinis HUS siejamas su preeklampsija. Todèl PHUS galètų būti ịtartas moterims, kurioms diagnozuota preeklampsija.

\section{Ivadas}

Hemolizinis ureminis sindromas (HUS) priklauso ligų, kurios vadinamos trombinėmis mikroangiopatijomis (TMA), grupei. TMA sukelia arteriolių ir kapiliarų endotelio pažeidimus, dèl kurių išsivysto: i) endotelio patinimas, jo atsiskyrimas nuo bazinès membranos ir baltymų bei ląstelių liekanų kaupimasis subendoteliniame tarpe; ii) kraujagyslių spindžio obstrukcija fibrino ir trombocitų krešuliais. Kai raudonieji kraujo kūneliai praeina per pažeistą kraujagyslę, sukeliama jų mechaninè hemolizè ir išsivysto trombocitopenija. Organų išemiją sukelia smegenų, širdies, plaučių, žarnyno ir inkstų kraujagyslių obstrukcija. HUS atveju dažniausiai sutrinka inkstų mikrocirkuliacija, todèl pasireiškia ūminis inkstų pažeidimas (angl. aute kidney injury - AKI). Taip pat galimas širdies nepakankamumas ar hipertenzijos sukeltos neurologinès komplikacijos. Apskritai ekstrarenalinès komplikacijos pasireiškia $20 \%$ atvejų [1-4].

Tipinis HUS yra susijęs su infekcija, tuo tarpu atipinis HUS (aHUS) su genetinèmis mutacijomis ir aplinkos veiksniais [1,2]. Su nėštumu susijęs aHUS (PHUS) sudaro 10-20\% visų aHUS atvejų [5]. Genetinès mutacijos buvo nustatytos 86 proc. moterų, kurioms buvo diagnozuotas PHUS. Tai galètų reikšti, kad něštumo metu vykstantys pokyčiai moters kūne inicijuoja komplementą reguliuojančių baltymų genų mutacijas, kurios pasireiškia sutrikusiu komplemento aktyvumu [1,2]. PHUS išsivysto $1 / 25000$ néščiųjų per metus ir gali joms sukelti dauginį organų pažeidimą. Paskutinès stadijos inkstų liga (angl. end stage renal disease - ESRD) išsivysto 60-70 proc. moterų; ESRD arba mirtis pasireiškia 50-80\% moterų; inkstų funkcijos sutrikimai ir arterinè hipertenzija neišvengiama toms, kurios išgyvena ūmini HUS epizodą $[1,3,6]$. 


\section{Atvejo aprašymas}

Paciente - 43 metų besilaukianti moteris (II-as nèštumas, 34-ta néštumo savaitė). Hospitalizacijos metu jos arterinis kraujospūdis (AKS) buvo 175/103 $\mathrm{mmHg}$, matomos edemos ant veido ir galūnių, tyrimuose proteinurija - 2,0 g/l. Nustatyta preeklampsija, todèl alfametildopa (Dopegyt) ir labetalolis skirti hipertenzijai gydyti. AKS nemažejo, sutriko placentos kraujotaka, išliko proteinurija, progresavo edema. Cezario pjūvis buvo atliktas trečiają hospitalizacijos dieną.

2-ą dieną po cezario pjūvio pacientei išsivystè sunki trombocitopenija, hemolizinè anemija ir ūminis inkstų pažeidimas. Laboratoriniai tyrimai parodè sumažèjusią hemoglobino $(\mathrm{Hb})$ koncentraciją kraujyje $(66 \mathrm{~g} / \mathrm{l})$, padidèjusią laktato dehidrogenazės (LDH) koncentraciją kraujyje (503 U/1), sumažejjusị haptoglobino kiekị ir trombocitų skaičių $(0,77 \mathrm{~g} / 1$ ir $75 \times 10^{9} / 1$ atitinkamai). Kreatinino ir šlapalo koncentracijos kraujyje buvo padidejusios $(387 \mu \mathrm{mol} / 1$ ir $11,7 \mathrm{mmol} / \mathrm{l}$ atitinkamai), nustatyta hiperkalemija $(5,8 \mathrm{mmol} / \mathrm{l})$ ir hiponatremija $(129 \mathrm{mmol} / \mathrm{l})$. Pacientei fiksuotas teigiamas skysčių balansas (+7000 ml per 2 dienas). Labetalolio kontrolèje pacientès AKS svyravo nuo 150/90 mmHg iki 130/80 mmHg, išliko kojų edema, todèl antihipertenzinis gydymas buvo tęsiamas toliau. 3-ią dieną po cezario pjūvio pacientès inkstų funkcija ir anemija pablogejo. Krūtinès rentgenografija parodè skysčių sankaupas pleuros ertmèje, vèliau buvo diagnozuota ir plaučių edema. Imunologiniai tyrimai - Kumbso testas ir antifosfolipidinių antikūnų (aFL Ak) testai buvo neigiami. Komplemento tyrimai neparode alternatyvaus kelio aktyvumo padidèjimo. Kepenų fermentai ir krešèjimo funkcija taip pat buvo be nukrypimų. Véžio žymuo CA 15-3 neparodè krūties véžio recidyvo (tirtas, nes pacientei $2005 \mathrm{~m}$. buvo diagnozuotas krūties vėžys, o $2013 \mathrm{~m}$. krūties vėžio recidyvas). Esat TMA įtarimui, buvo tirtas proteazès, surišančios Von Vilebrando faktorių (ADAMTS13), aktyvumas, pacientei pradètos plazmaferezès bei hemodializès procedūros. 4-tą dieną po cezario pjūvio pacientei buvo pastebèta poodinè hematoma kaulų čiulpų biopsijos punkcijos vietoje. Atlikta kompiuterine tomografija, kuria siekta įvertinti hematomą ir galbūt aptikti tolimąsias krūties vėžio metastazes. Metastazių neaptikta, tačiau rastas aktyvus arterinis kraujavimas iš $a$. glutea superior sin. ramus profundus (a. iliaca interna sin. baseinas). Kraujavimui sustabdyti atlikta embolizacija. Kojų venose nenustatyta kraujo krešulių, taip pat nebuvo rasta širdies embolizacijos požymių. aHUS diagnozè patvirtinta ivertinus ADAMTS13 aktyvumą (jis buvo normos ribose - 36,4\%). Paskirto gydymo metu hemoglobino koncentracija buvo palaikoma didesné nei $90 \mathrm{~g} / \mathrm{l}$ (jei reikia, skiriamos eritrocitų transfuzijos). Laboratoriniai tyrimai pradejo gerèti 9-tą dieną po cezario pjūvio, todèl 11-tą dieną pacientè buvo perkelta iš intensyviosios terapijos skyriaus ị nefrologijos skyrių. 12-16 dienomis haptoglobino kiekis sumažèjo iki visai nežymaus $(<0,08 \mathrm{~g} / \mathrm{l})$, D-dimeru koncentracija buvo $3390 \mathrm{mg} / \mathrm{l}$, bilirubino kiekis padidèjęs iki 34,4 $\mu \mathrm{mol} / \mathrm{l}, \mathrm{LDH}$ iki 503 U/l, C reaktyvus baltymas (CRB) iki 19,3 mg/l, pacientė karščiavo. Kraujo ir šlapimo pasèlių tyrimai bakterijų augimo neparodé, viršutinių kvèpavimo takų virusų infekcija buvo atmesta pasitelkiant molekulinius tyrimus. Galūnių ultragarsu aptiktas kraujo krešulys vienoje iš kairès kojos $v v$. peroneales. Pacientei buvo skirtas mažos molekulinès masès heparinas (MMMH) - Sol. Nadroparinum calcium $(0,3 \mathrm{ml}$ 1 kartą per dieną, vẻliau $0,3 \mathrm{ml} 2$ kartus per dieną i poodị).

24 dieną buvo nuspręsta nutraukti gydymą plazmaferezèmis, nes pacientès trombocitų koncentracija buvo didesnè nei $150000 / \mathrm{mm}^{3}\left(315 \times 10^{9} / 1\right)$, o hemoglobino koncentracija didesnè nei $100 \mathrm{~g} / 1(130 \mathrm{~g} / \mathrm{l})$. Iš viso pacientei buvo atlikta 14 plazmaferezių. Inkstų funkcija atsinaujino po 6 hemodializès procedūrų (kreatininas krito iki $74 \mu \mathrm{mol} / \mathrm{l}$ ). Išrašymo dieną pacientès AKS buvo 110/60 mmHg, svoris - $65 \mathrm{~kg}$, nebuvo edemos požymių, dusulio, LDH sumažèjo iki 263 $\mathrm{U} / 1$, haptoglobinas buvo normos ribose $(0,61 \mathrm{~g} / \mathrm{l})$. Beta adrenoblokatoriai ir angiotenzino II receptorių antagonistai buvo skirti hipertenzijai gydyti.

\section{Diskusija}

Moterims, kurioms diagnozuota preeklampsija, yra nustatytos komplementą reguliuojančių baltymų genų mutacijos. Lyginant su bendraja populiacija, preeklampsija dažniau pasitaiko moterims su tokiomis genų mutacijomis $(7,4$ proc. palyginti su 4-5 proc. bendrojoje populiacijoje) [5]. Taigi manoma, jog preeklampsijos išsivystymas rodo, kad komplementą reguliuojančių baltymų genuose yra mutacija, todėl komplementas negali susitvarkyti būkliu, didinančių jo aktyvumą, pvz., néštumo metu [7-9]. Siūlomas toks preeklampsijos išsivystymo mechanizmas: komplementą reguliuojančių baltymų genų mutacijos sąlygoja per dideli komplemento aktyvumą, kuris sukelia placentos pažeidimus, sutrikusį placentos vystymąsi, padidejjusi endotelio aktyvumą ir antiangiogeninių faktorių, toksiškų glomerulų endoteliui, smegenų voratinklinio dangalo rezginiams ir kepenu sinusoidems, išsiskyrimą [10,11]. Taip pat manoma, kad aHUS išsivysto kaip preeklampsijos komplikacija. Tai pagrindžiama teorija, kad abi būklès turi tą pačią patogenezę, kuri apima komplementą reguliuojančių baltymų genų mutacijas $[8,9,11]$.

Pacientei, kuriai po gimdymo išsivystė mechaninè neimuninè hemolizinè anemija, trombocitopenija ir ūminis inkstų pažeidimas, siekiant nustatyti PHUS diagnozę, būtina diferencine diagnostika [1-4]. Visoms atliekamas tyrimas dèl Shiga toksiną išskiriančios Escherichia coli sukelto HUS (STEC-HUS). Visoms nustatomas ADAMTS13 aktyvumas. Kraujas tyrimui turi būti imamas prieš plazmaferezes. Tik 
ADAMTS13 aktyvumas, mažesnis nei 10\%, yra reikšmingas trombinès trombocitopeninès purpuros (TTP) rodiklis. Su nèštumu susijusi TTP atsiranda antrojo ar trečiojo néštumo trimestrais, vidutiniškai 23 savaitę. Lyginant su aHUS pacientais, sergantiems TTP inkstų liga paprastai būna lengva (kreatininas $<17-23 \mathrm{mg} / \mathrm{l})$, o trombocitopenija sunkesnè $(<30$ $\left.\times 10^{9} / 1\right)$. Pacienčiu su TTP teigiamas atsakas ị plazmaferezes pasireiškia per 3-5 dienas, o aHUS pacienčių atsakas tokiu laikotarpiu geriausiu atveju būna dalinis - gerẻja hematologiniai parametrai, tačiau organų funkcijos toliau blogejja ir pagerejja tik po 5 ar daugiau dienų. Manoma, kad diseminuota intravaskulinè koaguliacija (DIK) ir reikšmingas kepenu funkcijos sutrikimas reikštų HELLP (hemolizè, padidèję kepenų fermentai, mažas tormbocitų skaičius) sindromo arba ūminès néščiųjų steatozès diagnozę, o DIK nebuvimas ir santykinai normalūs kepenų fermentai atitinka TTP arba aHUS diagnozę. DIK ir HELLP sindromai paprastai yra susiję su preeklampsija (padidejusiu AKS, galvos skausmu, edema) ir dešiniojo viršutinio kvadranto pilvo skausmu. Maždaug $70 \%$ atvejų HELLP sindromas atsiranda nèštumo laikotarpio pabaigoje, o po gimdymo iškart išsisprendžia. Negenetinis aHUS gali būti sukeltas autoimuninių ligų, tokių kaip antifosfolipidinis sindromas. Tokiu atveju kraujyje randami autoimuniniai antikūnai. Jie sudaro imuninius kompleksus ir aktyvuoja komplemento sistemą klasikiniu keliu. HUS ir TTP gali būti tiesiogiai siejamas su piktybiniu naviku arba su chemoterapiniais vaistais ir/arba radioterapija [13-15].

Manome, kad šiuo atveju nèštumas parodè, kad moteris turi komplementą reguliuojančių baltymų genų mutacijas. Jos sąlygojo komplemento aktyvumo padidejjimą, dèl to išsivyste preeklampsija, kuri po gimdymo neišsisprendè, bet buvo komplikuota HUS. PHUS rizika yra didžiausia antrojo néštumo laikotarpiu, $80 \%$ moterų jis pasireiškia po gimdymo $[5,8]$. aHUS paprastai pasireiškia moterims per tris menesius po gimdymo [6].

\section{Išvados}

PHUS turètų būti ịtartas, jei anemija, trombocitopenija ir üminis inkstų nepakankamumas moteriai pasireiškia per 3 mènesius po gimdymo. PHUS diferncijuojamas nuo STECHUS, TTP, HELLP sindromo ir riebalinès néščiujų steatozès. İtariama, kad komplementą reguliuojančių baltymų genų mutacijos susijusios su preeklampsijos vystymusi, o atipinis HUS yra susijęs su preeklampsija. Taigi, pacientes su preeklampsija, reikia įtarti dèl PHUS išsivystymo [1-4].

Jei TMA ir AKI atsiranda po nėštumo, tačiau kepenų fermentai nėra padidèję ir DIK sindromas atmetamas, infekcijos išmatose nèra, o ADAMTS13 lygis $\geq 10 \%$, aHUS yra labai tikètinas. Ypač jei minèta būklè atsiranda pacientei, kuriai néštumo metu diagnozuota preeklampsija, kuri po gimdymo neišsisprendè [13-15].
Moterys, kurioms diagnozuota preeklampsija, po gimdymo reikia atidžiai stebèti. Jei įtariamas phUS, reikètų apsvarstyti ankstyvą antikomplimentinę terapiją. Ypač svarbu stebèti ir gydyti pacientes, turinčias inkstų funkcijos nepakankamumą, nes jos turi didesnę staigios mirties, dèl smegenų išemijos ar širdies komplikacijų riziką $[7,8,10,11]$.

Moterys, kurioms nustatytos komplementą reguliuojančiu baltymų genų mutacijos, turètų būti informuotos apie $20 \%$ padidejusią PHUS riziką, todẻl bet kokị šių moterų nèštumą reikia atidžiai stebèti [6].

\section{Literatūra}

1. Campistol JM, Arias M, Ariceta G, Blasco M, Espinosa L, Espinosa M, Grinyó JM, Macía M, Mendizábal S, Praga M, Román E, Torra R, Valdés F, Vilalta R, Rodríguez de Córdoba S. An update for atypical haemolytic uraemic syndrome: diagnosis and treatment. A consensus document. Nefrologia 2015;35(5):421-47.

https://doi.org/10.1016/j.nefro.2015.07.005

2. Kavanagh D, Goodship TH, Richards A. Atypical hemolytic uremic syndrome. Semin Nephrol 2013 Nov;33(6):508-30.

https://doi.org/10.1016/j.semnephrol.2013.08.003

3. Franchini M. Atypical hemolytic uremic syndrome: from diagnosis to treatment. Clin Chem Lab Med 2015 Oct;53(11):167988.

https://doi.org/10.1515/cclm-2015-0024

4. Shen YM. Clinical evaluation of thrombotic microangiopathy: identification of patients with suspected atypical hemolytic uremic syndrome. Thromb J 2016 Oct 4;14(Suppl 1):19.

https://doi.org/10.1186/s12959-016-0114-0

5. Fakhouri F, Roumenina L, Provot F, Sallée M, Caillard S, Couzi L, Essig M, Ribes D, Dragon-Durey MA, Bridoux F, Rondeau E, Frémeaux-Bacchi V. Pregnancy-associated hemolytic uremic syndrome revisited in the era of complement gene mutations. J Am Soc Nephrol 2010 May;21(5): 859-867.

https://doi.org/10.1681/ASN.2009070706

6. Noris M, Bresin E, Mele C, Remuzzi G. Genetic atypical hemolytic-uremic syndrome. 2007 Nov 16 [updated 2016 Jun 9]. In: Adam MP, Ardinger HH, Pagon RA, Wallace SE, Bean LJH, Stephens K, Amemiya A, editors. GeneReviews ${ }^{\circledR}$ [Internet]. Seattle (WA): University of Washington, Seattle; 1993-2018. Internetinè prieiga: http://www.ncbi.nlm.nih.gov/ books/NBK1367/

7. Saad AF, Roman J, Wyble A, Pacheco LD. Pregnancy-associated atypical hemolytic-uremic syndrome. AJP Rep 2016 Mar;6(1):e125-8. https://doi.org/10.1055/s-0036-1579539

8. Scully M. Thrombotic thrombocytopenic purpura and atypical hemolytic uremic syndrome microangiopathy in pregnancy. Semin Thromb Hemost. 2016 Oct;42(7):774-779.

https://doi.org/10.1055/s-0036-1587683 
9. Fremeaux-Bacchi V, Fakhouri F, Garnier A, Bienaimé F, Dragon-Durey MA, Ngo S, Moulin B, Servais A, Provot F, Rostaing L, Burtey S, Niaudet P, Deschênes G, Lebranchu Y, Zuber J, Loirat $\mathrm{C}$. Genetics and outcome of atypical hemolytic uremic syndrome: a nationwide French series comparing children and adults. Clin J Am Soc Nephrol 2013 Apr;8(4):554-62.

https://doi.org/10.2215/CJN.04760512

10. Salmon JE, Heuser C, Triebwasser M, Liszewski MK, Kavanagh D, Roumenina L, Branch DW, Goodship T, FremeauxBacchi V, Atkinson JP. Mutations in complement regulatory proteins predispose to preeclampsia: a genetic analysis of the "Promisse" Cohort. PLoS Med. 2011 Mar; 8(3): e1001013. https://doi.org/10.1371/journal.pmed.1001013

11. Fakhouri F. Pregnancy-related thrombotic microangiopathies: clues from complement biology. Transfus Apher Sci 2016 Apr;54(2):199-202.

https://doi.org/10.1016/j.transci.2016.04.009

12. Thomas MR, Robinson S, Scully MA. How we manage thrombotic microangiopathies in pregnancy. Br J Haematol 2016 Jun;173(6):821-30. https://doi.org/10.1111/bjh.14045

13. Mannucci PM, Cugno M. The complex differential diagnosis between thrombotic thrombocytopenic purpura and the atypical hemolytic uremic syndrome: Laboratory weapons and their impact on treatment choice and monitoring. Thromb Res 2015 Nov;136(5):851-4.

https://doi.org/10.1016/j.thromres.2015.09.007

14. Cataland SR, Wu HM. Atypical hemolytic uremic syndrome and thrombotic thrombocytopenic purpura: clinically differentiating the thrombotic microangiopathies. Eur J Intern Med 2013 Sep;24(6):486-91. https://doi.org/10.1016/j.ejim.2013.05.007

15. Gupta M, Feinberg BB, Burwick RM. Thrombotic microangiopathies of pregnancy: differential diagnosis. Pregnancy hypertens 2018 Feb 16;12:29-34.

https://doi.org/10.1016/j.preghy.2018.02.007

\section{PREGNANCY RELATED ATYPICAL HEMOLYTIC} UREMIC SYNDROME: CASE REPORT

\section{D.Maldžiūtė, E.Mačionienė, M.Miglinas, L.Rimševičius}

Key words: pregnancy, preeclampsia, thrombotic microangiopahies, acute kidney injury, aHUS.

Summary

Background. Hemolytic uremic syndrome (HUS) belongs to a group of disorders called thrombotic microangiopathies (TMA). These induce small vessel wall thickening and obstruction of vascular lumen resulting in mechanical and non-immune hemolytic anemia, thrombocytopenia and, in case of HUS, an acute kidney injury as a consequence of ischemia. Pregnancy related atypical HUS (PHUS) affects $1 / 25000$ pregnancies per year and can cause multiple organ damage. $60-70 \%$ of affected women develop end stage renal disease (ESRD) after primary onset of HUS.

Case report. We report a 43 year old woman who was diagnosed with preeclampsia during third trimester (34th week) of pregnancy. Hemolytic anemia (hemoglobin $66 \mathrm{~g} / \mathrm{L}$, lactate dehydrogenase 503 $\mathrm{U} / \mathrm{L}$, haptoglobin $<0.77 \mathrm{~g} / \mathrm{L})$, thrombocytopenia $\left(75^{*} 10 \mathrm{e} 9 / \mathrm{L}\right)$ and acute kidney injury requiring dialysis occurred on 2nd day following Caesarean section. The patient was diagnosed with PHUS due to normal liver function and normal Von Willebrand factorcleaving protease activity level. She was treated with plasmapheresis (14 procedures). Renal function recovered after 6 hemodialysis procedures. Beta-adrenoblockers and angiotensin II receptor blockers were prescribed for the treatment of hypertension.

Conclusions. PHUS should be suspected if anemia, thrombocytopenia and acute renal failure occur within 3 months after delivery. It has to be differentiated from thrombotic thrombocytopenic purpura (TTP), HELLP (hemolysis, elevated liver enzymes, low platelets count) syndrome and acute fatty liver of pregnancy (AFLP). Mutations in complement regulatory proteins are found in women with preeclampsia. Moreover, atypical HUS is associated with preeclampsia. Thus, one should suspect PHUS in a patient with preeclampsia.

Correspondence to: diana.maldziute@gmail.com

Gauta 2018-05-19 